- Gi rask respons på artikler gjennom artikkelens kommentarfelt på tidsskriftet.no Respons som er postet innen én måned etter at artikkelen er publisert, vurderes for publisering som Brev til redaktøren i papirutgaven.

Redaksjonen forbeholder seg retten til å foreta redaksjonelle endringer.

Forfattere av vitenskapelige artikler har tilsvarsrett, jf. Vancouver-gruppens regler.

\section{Alternativ tolkning av begrepet pasient}

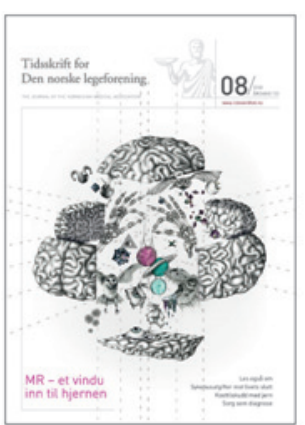

Erlend Hems lederartikkel om pasientbegrepet i Tidsskriftet nr. 8/2013 (1) er viktig fordi han implisitt drøfter pasientens rolle og dermed maktbalansen i legepasient-forholdet.

Det er imidlertid en aktuell tolkning av ordet «pasient» som ikke er tatt med, som har sin bakgrunn langt tilbake i tid. Nyere forskning på de mest nedstøvede delene av Dødehavsrullene tyder på at noen vers i 1 Mos 3, 24 (2) ble utelatt under kanoniseringen av bibelens bøker fordi man på det tidspunkt ikke skjønte deres betydning. De lød omtrent som følger: «Du skal streve med syk-dom, tilstander som i ulik grad og i ulikt tempo bryter ned din kropp. Mange må sågar slite med dette kronisk. Men - jeg vil også gi deg et vesen, Helsevesenet. Der skal du få hjelp for dine plager.» Videre er det også funnet fragmenter av en beskrivelse av Helsevesenet. Her fremgår det at: « Helsevesenet har en innebygd svakhet: Du må alltid vente, noen ganger kort, noen ganger lenge, ja - noen ganger på ubestemt tid. Dette skal gjelde for alle land over hele jorden. Derfor skal du, når du strever med sykdom kalles - tålmodig -.» Dette er, som den våkne leser vil merke seg, det vesentlige punktet i denne saken.

På et senere tidspunkt, under det engelske imperiets storhetstid, fant man ut at Norge var et lite land og at det norske ordet «tålmodig» derfor var uegnet. Dette var et globalt fenomen, og man ville derfor bruke et språk som alle forsto. Valget falt på den engelske oversettelsen «patient», for den brukte Florence Nightingale. Pasient er en fornorskning fra nyere tid.

Uansett hva man mener om det vitenskapelige grunnlaget i saken, vil denne tolkningen av begrepet «pasient» ha stor betydning for forståelsen av lege-pasient- forholdet $\mathrm{i}$ dagens Norge, og drøftingen har derfor, etter undertegnedes syn, en viss relevans.

\section{Johannes Kolnes}

johannes.kolnes@helse-bergen.no

Johannes Kolnes (f. 1951) er spesialrådgiver i Avdeling for helsetjenesteutvikling ved Haukeland universitetssjukehus.

Ingen oppgitte interessekonflikter.

Litteratur

1 Hem E. Pasient, klient, bruker eller kunde? Tidsskr Nor Legeforen 2013; 133: 821

2. Bibelen. 1 Mos 3,24

Dette er en redigert versjon av et innlegg publisert som rask respons på nett 9.5. 2013. http://tidsskriftet.no/article/2996612/

\section{Pasientbegrepet fra pasientens side}

Pasient, klient, bruker eller kunde? spør redaktør Erlend Hem i Tidsskriftet nr. 8/2013 (1). Han sier at begrepet pasient har sine svakheter, men at alternativene er dårlige, og etterlyser pasientenes syn. Som pasient i første- og annenlinjetjenesten og engasjert innen somatikk og psykiatri - her er min respons på begrepene.
Jeg har type 1-diabetes og går til konsultasjon hos endokrinolog. I psykiatrien går jeg i psykoterapi (konsultasjon). Jeg er i rollen som pasient når jeg er i en konsultasjon. Når jeg er hjemme, er jeg ikke i rollen som pasient, men i andre roller, som f.eks. mor. Legen er heller ikke lege når han er hjemme, da er han i rollen som for eksempel far. Under konsultasjonen er jeg i pasientrollen og han i legerollen. Jeg har rettigheter etter pasient- og brukerrettighetsloven, og han må forholde seg til blant annet helsepersonelloven. Rollen er avgrenset og lovfestet.

$\AA ̊$ være i rollen som pasient betyr ikke at jeg er syk fordi jeg har en eller flere sykdommer, like lite som du trenger å være syk fordi du våkner sengeliggende.

Bruker er et dårlig begrep. Man kan ikke skrive bruker uten å definere hva man er bruker av. Er det E39, stiene til Turistforeningen, SAS eller et sprøyterom? Tidligere rusmisbrukere likte ikke å bli kalt brukere.

Kunde er ubrukelig. Når jeg må benytte meg av helsehjelp fordi jeg har fått en sykdom, som jeg i utgangspunktet ikke vil ha, vil jeg ikke bli kalt kunde. Og jeg har heller ikke alltid rett.

Klient er greit til sitt bruk. Jeg er i rollen som klient hos NAV eller hos min advokat. Klient er også bare en rolle, et forståelig begrep, selv om det stammer fra antikken.

Og til slutt: Det heter ikke sykehjem lenger. De aller fleste heter beklageligvis Bo- og aktivitetssenter, såkalt BOAS. Her blir det naturlig å kalle personen for beboer. Hvis det fortsatt finnes sykehjem, er nok beboer den beste benevnelsen der også, siden de faktisk bor der. Beboeren kan også være i rollen som pasient når situasjonen tilsier det, på lik linje som beboeren også er i rollen som oldemor, ektefelle eller venninne i andre situasjoner.

$\AA ̊$ omdefinere begrep endrer ingenting - ei heller hvordan jeg ser på meg selv. Pasientbegrepet har få svakheter, det er klart og greit, og alternativene er uansett dårligere.

Ble du noe klokere, Hem?

\section{Målfrid Frahm Jensen}

mj@frahmjensen.com

Målfrid Frahm Jensen (f. 1963) er erfaringskonsulent, pasient og pårørende. Hun arbeider ved Stavanger universitetssjukehus.

Ingen oppgitte interessekonflikter.

Litteratur

1. Hem E. Pasient, klient, bruker eller kunde? Tidsskr Nor Legeforen 2013; 133 : 821

Dette er en redigert versjon av et innlegg publisert som rask respons på nett 24.4. 2013. http://tidsskriftet.no/article/2996612

\section{E. Hem svarer:}

Jeg takker Johannes Kolnes for en oppsiktsvekkende nærlesning av Dødehavsrullene. Det er riktig at «Pasient er en fornorskning fra nyere tid»-det var ved rettskrivningsreformen i 1938 at skrivemåten ble endret fra «patient» til «pasient» (1).

«Å omdefinere begrep endrer ingenting», skriver Målfrid Frahm Jensen. Likevel er det ofte det som skjer. Dette er samme diskusjon som den kanadiske psykologen Steven Pinker kaller for «den eufemistiske tredemølle», dvs. at belastede ord erstattes med andre ord som igjen byttes ut med nye (2). Et eksempel er hvordan krøpling 
ble erstattet av vanfør $>$ handikappet $>$ funksjonshemmet $>$ person med funksjonshemning $>$ person med nedsatt funksjonsevne, eller hvordan gamlehjem ble til aldershjem $>$ sykehjem $>$ bolig for eldre $>$ bo- og rehabiliteringssenter (3). Man forsøker seg på omskrivninger og nye måter å si vanskelige ting på, men som regel varer det ikke lenge før de negative konnotasjonene følger etter, som nissen på lasset. Når et ord blir negativt ladet, finner vi på et nytt. Det blir fort en lang, lang rekke (3).

Antakelig spiller det ikke så stor rolle hva Frahm Jensen og jeg måtte mene. Dersom mange nok synes at «pasient» er et ugreit begrep, ja, da blir det nok ugreit (4).

\section{Erlend Hem}

erlend.hem@medisin.uio.no

Erlend Hem (f. 1970) er dr.med. og assisterende sjefredaktør i Tidsskriftet. Ingen oppgitte interessekonflikter.

\section{Litteratur}

1. Ny rettskrivning 1938: bokmål: regler og ordliste: utarbeidd etter tiltak av Kirkeog undervisningsdepartementet. Oslo: Olaf Norlis forlag. 1938: 45.

2. Hem E. Det vanskelige ordet angivelig. Tidsskr Nor Legeforen 2012; 132: 1637.

3. Halvorsen BE. Utgått på dato. A-magasinet 16.3.2012: 26-31.

4. Lund J. Negre, sopere, krøplinger og idioter. Aftenposten 12.4.2013. www.aftenposten.no/meninger/kommentarer/

Negre_-sopere_-kroplinger-og-idioter-7171818.html (3.6.2013)

\section{Akuttfaseprotein og/eller jernlager}

Jeg viser til oversiktsartikkelen av Ulvik og medarbeidere i Tidsskriftet nr. 8/2013 om kosttilskudd ved jernmangel, hvor de beskriver effekten av jerntilskudd hos friske voksne forsøkspersoner med jernmangel (1). Jeg ønsker å utfordre enkelte biokjemiske analyser og resultater presentert i studien.

Ferritin er et akuttfaseprotein og stiger ved aktive prosesser. I studien er det en god beskrivelse av plagsomme bivirkninger ved bruken av både hemjern og jernsalt. Det oppgis at $58 \%$ av deltakerne i høydosegruppen rapporterte om symptomer på gastrointestinale bivirkninger. Samtidig vises det til en økning i ferritin fra $9,5 \mu \mathrm{g} / \mathrm{l}$ til $22,5 \mu \mathrm{g} / \mathrm{l}$, og endringen tolkes som økte jernlagre etter jernbehandling.

I lavdosegruppen måles stigningen i ferritin fra $10 \mu \mathrm{g} / \mathrm{l} \mathrm{til} 17 \mu \mathrm{g} / \mathrm{l}$, med innrapporterte symptomer på gastrointestinale bivirkninger hos $35 \%$ av forsøkspersonene.Konklusjonen er at stigningen av ferritin kan skyldes bivirkningene, snarere enn økte jernlagre, og at høydosejern forårsaket større bivirkninger enn lavdosejern.

I studien viser man også til stigningen i hemoglobin i høydosegruppen fra $12,5 \mathrm{~g} / \mathrm{dl}$ til $12,9 \mathrm{~g} / \mathrm{dl}$, og i lavdosegruppen fra $12,8 \mathrm{~g} / \mathrm{dl}$ til 13, $2 \mathrm{~g} / \mathrm{dl}$. Endringene betegnes som signifikante.

På basis av analysevariasjon $1 \%$ og intraindividuell biologisk variasjon på $3 \%$ mener jeg imidlertid at forskjellen burde ha endret seg med mer enn $8 \%$ for at endringen skulle bli statistisk signifikant (2). Etter mitt skjønn kan endringen i hemoglobin på $0,4 \mathrm{~g} / \mathrm{dl}$ dermed ikke være signifikant, da stigningen måtte vært på minst $1,0 \mathrm{~g} / \mathrm{dl}$.

\section{Krystyna Sandvik}

krystyna.sandvik@ous-hf.no

Krystina Sandvik (f. 1959) er bioingeniør ved Avdeling for medisinsk biokjemi, Oslo universitetssykehus, Rikshospitalet.

Ingen oppgitte interessekonflikter.

\footnotetext{
Litteratur

1. Ulvik RJ, Møller R, Hervig T. Kosttilskudd med jern ved jernmangel. Tidsskr Nor Legeforen 2013; 133: 845-9.

2. Lyngbye J, Kjær A, Ladefoged S et al. red. Lyngbyes laboratoriemedicin. København: Nyt Nordisk Forlag Arnold Busck, 2010.
}

\section{R. J. Ulvik svarer:}

Krystyna Sandvik stiller et interessant spørsmål om økningen i s-ferritin kan skyldes en akuttfasereaksjon forårsaket av toksiske reaksjoner i tarmen som er utløst av jerntabletter. Det forutsetter i så fall at akuttfasereaksjonen har en styrke og varighet som er stor nok til å stimulere syntese av ferritin og gi en forbigående økning av s-ferritin. Alvorlighetsgraden vurderes ut fra det kliniske bildet med feber som et viktig symptom, og om det er økning av andre akuttfasereaktanter, særlig CRP (1). I vår studie var de kliniske bivirkningene av det milde slaget i form av obstipasjon, diaré og mageknip. Ferritinnivået i serum var jevnt økende, og ingen fikk påvist økt CRP-nivå. Det er derfor lite sannsynlig at behandlingen utløste en akuttfasereaksjon som var alvorlig nok til alene å forklare økningen i s-ferritin.

Sandvik stiller også spørsmål om økningen av medianverdien for hemoglobin innen behandlingsgruppene er signifikant. Vi har brukt Wilcoxons signed ranks-test som viser hvor mange innen gruppen som fikk høyere hemoglobin enn utgangsverdien i løpet av behandlingen (2). Testen sier intet om størrelsen på endringene, men beregner sannsynligheten for at økning i hemoglobin hos deltakerne i gruppen er tilfeldig. Dette punktet kunne vært bedre presisert i artikkelen. Sandvik har på sin side med utgangspunkt i analytisk og biologisk variasjon beregnet hvor stor forskjellen må være på to etterfølgende hemoglobinprøver hos en og samme person, for at den skal være statistisk signifikant. Men det er en annen problemstilling enn vi hadde i vår studie.

Rune J. Ulvik

rune.ulvik@med.uib.no

Rune J. Ulvik (f. 1947) er professor ved Klinisk institutt 2 ved Det medisinsk-odontologiske fakultet, Universitetet i Bergen.

Ingen oppgitte interessekonflikter.

Litteratur

1. Eskeland B, Baerheim A, Ulvik RJ et al. Influence of mild infections on iron status parameters in women of reproductive age. Scand J Prim Health Care 2002; 20: 50-6.

2. Altman DG. Practical statistics for medical research. London/New York, NY Chapman \& Hall/CRC, 1991: 187-9.

\section{RETTELSE}

En helsedirektør for vår tid

Kari Tveito

Tidsskr Nor Legeforen 2013, 133: 838-40

I intervjuet med Bjørn Guldvog i Tidsskriftet nr. 8/2013 side 838 nevnes «helseøkonom Hans Petter Waaler». Det skulle stått: sosialøkonom Hans Thomas Waaler.

Vi beklager feilen. 